\title{
Gender Perspective in Agroforestry Teaching and Research
}

\author{
Perspective
}

Volume 2 Issue 2- 2021

\begin{abstract}
Author Details
Vila-Lameiro $\mathrm{P}^{\star}$, Conde-Fernández A

Agroforestry Engineering Department, University of Santiago de Compostela, Spain
\end{abstract}

*Corresponding author

Vila-Lameiro P, Agroforestry Engineering Department, Engineering High Politechnical School, University of Santiago de Compostela, Universitary Campus s/n, 27002-Lugo, Spain

Article History

Received: June 03, 2021 Accepted: June 04, $2021 \quad$ Published: June 04, 2021

\section{Perspective}

Equal access to science is not only an ethical, moral and social requirement for human development [1]; it's also a necessity to take advantage of the potential of the scientific community and guide its progress, satisfying humanity needs [2]. It is urgently necessary to solve problems that women, who constitute more than half of the world's population, have to face in order to start a scientific career, continue it, be able to promote and participate in decision-making in science and technology [3]. In history, women participated in scientific knowledge, generating forms of production and transformation of raw materials, through their practical contributions, but in most cases, they lacked the theoretical knowledge to apply them. In the agroforestry environment his involvement in practical work went beyond mere research.

The incorporation of calculations and theoretical studies in knowledge, gave rise to a specialized language, initially inaccessible for women [4]. However, despite their exclusion from a scientific sphere, many women managed to overcome their marginalization and excel in certain scientific fields. For example, in the forestry field, even in the 1960s, the intention of women to train in an exclusive profesion of the male was incomprehensible and it was necessary to wait until 1974 for Lutgarda Domínguez Yanes to become the first PhD. Forest Engineer in Spain. Before she had to overcome the effort of her own training and overcome the reluctance of the teachers themselves, reluctant to admit women into her classrooms. At present, within the agricultural and forestry sector, there is a long way to achieve effective equality between women and men. 50 years later, they have not been enough to end gender stereotypes, which have left women in a disadvantaged position, resulting in a society, which claims to be advanced, wasting the capacity, intelligence and contribution of half of their citizenship.

Today, the situation of women with regard to access to higher education is similar to men. However, although the student is mostly female and they are also the first to finish their studies, this situation is often unequal in terms of number of teachers, boss department, university rectors and, ultimately, the majority of positions of responsibility. As was reflected in the International Congress on Women in Physics: "Only when women fully participate as researchers and scientific directors in laboratories, as teachers and, making decisions at the highest level, will they feel like full partners in the technological society" [5]. It is evident that to overcome the current dominance of men in the scientific and technological system, it is necessary for women to have access to scientific practice, achieving gender parity from education and research.

The importance of introducing the "gender perspective" in the university curriculum is based on three lines [6]: (i) make visible the participation of women in the careers they study; (ii) make their contributions visible and (iii) build new knowledge.

In this sense, the research group GI-1720 of the University of Santiago de Compostela (USC), coordinated by Dr. D ${ }^{a}$ M. Dolores Fernández and constituted by researchers from the agroforestry field, is aware of the importance of incorporating the gender perspective in the construction of scientific knowledge, not only through the theoretical and practical contributions of research lines, also through the social transformations that they imply. Currently, any research that seeks to explain reality must introduce the behavior differences, experiences and opportunities between women and men into its analytical models [7].

For almost 10 years, in the GI-1720 research group an experience based on the implication of the gender perspective in relation to equal incorporation of the students of the last year of degrees in Agronomic and Forestry Engineering has been developed. Specifically, they are students who already have an university degree and are beginning their Master's final work. In addition, newly graduated students with the possibility of accessing $\mathrm{PhD}$. studies are also included. Through 
this experience, it is intended to promote a more specialized training for women that allows them to access positions of responsibility [8].

The objectives are, on one hand, to increase the opportunities of women in the different stages of the scientific career and, in the other, the inclusion of different points of view that enrich discussion, observations and definition of new approaches in research. Due to this reason, the successful experience is based on the incorporation of students who are in the last stage of their training. To achieve these goals, it is necessary to promote continuity in their training among women.

\section{References}

1. Comisión Europea (2010) Stocktaking 10 years of Women in Science policy by the European Commission 1999-2009. Publications Office of the EU, Luxembourg.
2. VVAA (2011) Libro Blanco. Situación de las Mujeres en la Ciencia Española. Unidad de Mujeres y Ciencia. Madrid: Ministerio de Ciencia e Innovación.

3. www.unesco.org/science/wcs/esp/declaracion_s.htm

4. http://www.oei.es/noticias/spip.php?article1227

5. UNESCO (2002) Congreso Internacional sobre Mujeres en Física. Sede de la UNESCO (Maison de l'UNESCO). Francia

6. Fundación Española para la Ciencia y Tecnología (FECYT) (2005) Mujer y ciencia: la situación de las mujeres investigadoras en el sistema español de ciencia y tecnología. Programa de Análisis y Estudios, Ministerio de Educación.

7. Zinovyeva, N. y M. Bagues (2010). Does Gender Matter for Academic Promotion? Evidence from a Randomized Natural Experiment.

8. Ceci S, W Williams (2007) Why Aren't More Women in Science? The American Psychological Association. 